$\mathbb{T}$ periodica polytechnica

\author{
Social and Management Sciences

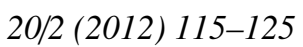 \\ doi: 10.3311/pp.so.2012-2.06 \\ web: http://www.pp.bme.hu/so \\ (c) Periodica Polytechnica 2012
}

RESEARCH ARTICLE

\section{Media competence and visual literacy - towards considerations beyond literacies}

\author{
Theo Hug
}

Received 2012-09-07

\begin{abstract}
Debates on media competency and media literacy are going on now for a few decades. Many concepts have been developed in various disciplines. Along with that, discourses on visual literacy have been intensified, too, although visuals have been used in educational contexts throughout history. But only recently, after almost three thousand years of historiography, turns like iconic turn, pictorial turn, and mediatic turn have been claimed. Visual competencies as well as competencies of visuals and their epistemological relevance are intensively discussed in arts, architecture, philosophy as well as in educational, communication, and media studies. In this situation, we are facing new conceptual challenges for media education and media literacy discourses. On the one hand, there is a long tradition of "visual education" and "aesthetic education", on the other hand, visual literacy, visual competency, media literacy, new literacies are being requested. The paper starts (1) with an outline of selected aspects of the debates on media competency and media literacy, followed (2) by a discussion of more recent concepts of 'visual competence' and 'visual literacy' and their relevance for media education. Finally (3), the contribution aims at sounding out conceptual alternatives to the literacification of everything and their relevance for media pedagogy and educational theory.
\end{abstract}

\section{Keywords}

media competence $\cdot$ media literacy $\cdot$ visual competence $\cdot$ visual literacy $\cdot$ literacification

\section{Theo Hug}

Institute of Psychosocial Intervention and Communication Studies, University of Innsbruck, Schoepfstr. 3 A - 6020 Innsbruck, Austria e-mail: theo.hug@uibk.ac.at

\section{Introduction}

Debates on media competency and media literacy are going on now for a few decades. While a diversity of understandings of media competency has been discussed particularly in German speaking countries, a multiplicity of media literacy approaches has been developed notably in the English speaking parts of our globe. Moreover, multitudinous compound terms such as 'key competencies', 'competence measurement', '(media) competence management', or 'information literacy', 'visual literacy', and 'computer literacy' are circulating currently 1 Even if we acknowledge different understandings of 'competence', David McClelland's statement - "A lot of people have jumped on the bandwagon. The danger is that they may not identify competencies properly" [1] - remains ambivalent. One the one hand, it still makes sense today in view of widespread loose forms of dealing with language and concepts. On the other hand, there are different conceptualizations being discussed (e.g. [14, 16]) and hegemonic claims are rather part of the problem than of the solution.

Looking at the term 'literacy', the situation is alike (e.g. [73 p. 55]). It has been fashionable for a while to generate new concepts of literality and literacy, transfer them to various areas and apply them in metaphorical ways [23,40,72]. Many descriptions of new literacies are pragmatically motivated, many are kept very simple [68], others are quite differentiated [58], and clearly focused [30]. But it is not only the variety of different conceptualizations and the multitude of compound terms which invites to rethink discursive developments. It is also the fact that sometimes different terms are used for similar phenomena, that unclear or hidden meanings are at work and that epistemological

\footnotetext{
${ }^{1}$ Of course, there are many more examples: action competence, coaching competence, cognitive competence, communicative competence, design competence, diversity competence, ecological competence, emotional competence, gender competence, intercultural competence, key competencies, leadership competence, meta competence, organizational competence, pornography competence, self competence, social competence, visual competence, etc. art literacy, consumer literacy, digital literacy, diversity literacy, ecological literacy, emotional literacy, environmental literacy, film literacy, food literacy, geographical literacy, health literacy, library literacy, multicultural literacy, numerical literacy, sexual literacy, television literacy, etc..
} 
shortcomings are often underestimated.

In this article I am going to provide an outline of selected aspects of the debates on media competency and media literacy as well as visual competence and visual literacy. Furthermore, I am questioning widespread tendencies of the literacification of (nearly) everything and pointing out promising conceptual alternatives. In doing so, the theory of medial forms [39] turns out to be both especially viable for the analysis of media cultural phenomena and also relevant for media pedagogy and educational theory.

\section{From media competence to new literacies - an out- line of recent debates}

Political, economic, scientific and everyday discourses agree that media have become increasingly significant. In fact, media and especially visuals have always been relevant to processes of human communication - no matter where you start in history. The trends and popularities have been quite variable, just like the corresponding relations between sense and sensuality, mediation and dissemination dynamics of knowledge, and not least epistemological and pedagogical hopes and concerns.

Today, it is generally conceded that media play a considerable part in the processes of growing up, the development of identities, values and everyday aesthetics, or the shaping of references to the self and the world. In short, it is largely beyond doubt that media are involved in the creation of realities and the formation of communicative processes, and that they have to be considered an agent of socialization. In this general sense they are granted quite constructive traits, also and especially when the influences and effects of media are judged as destructive.

However, when it comes to questions like how media shape and assess this role, how the regards can be specified and to what extent a consideration of media as a socializing agent is adequate, how media (can) play a role in educational contexts, opinions are divided. Perceptions differ tremendously, on the one hand with regard to scopes and characteristics of constructivity, mediality, and educativity ${ }^{2}$ in general. On the other hand, our conceptual points of departure are crucial, especially with respect to issues of communication, education, and participation.

\subsection{Media competence and media literacy}

Already when Dieter Baacke, one of the most influential media educationalists in the German-speaking world, argued for the relevance of the term 'competence' in media educational

\footnotetext{
${ }^{2}$ With the term 'educativity' I do not refer to a kind of metaphorical equation like educativity = education + creativity as Zeid Abdul-Hadi and others do (cf. http://www.ted.com/conversations/6747/what_does_the_term_educativit.html, accessed: May 22, 2012). Since there is no education without creativity this would be a tautological argument. I rather use the term as a translation for the German term 'Bildsamkeit' which refers to the human ability to learn and to educate oneself and which has been introduced into the pedagogical discourse by Johann Friedrich Herbart (1776-1841).
}

contexts, societal aspects of participation and the beginnings of debates about mediated lifeworlds (Lebenswelten) were important [3]. Thus, he conceptualized media competence as an aspect of communicative competence and subsequently refined the concept. In doing so, he gave the crucial impetus not only for the media-pedagogical debates on media competence but also for interdisciplinary connections and advancements. The term, in varied differentiations, has remained significant until today beyond the scope of media pedagogy, in the context of the theory and practice of education, social and cultural work as well as in the discourses of economy, politics, law, psychology, information science and technology.

While the majority of efforts in the area of media competence, both the practically and theoretically motivated, remained mostly limited to regional or national perspectives, the area of tension between media competence and media education (e.g. [64,71]) and attempts at international communication have recently gained significance [49]. In this context, particularly designations from the English-speaking world are attracting attention, such as the definition of media literacy by NAMLE ${ }^{3}(\mathrm{Na}-$ tional Association for Media Literacy Education):

"Media literacy empowers people to be both critical thinkers and creative producers of an increasingly wide range of messages using image, language, and sound. It is the skillful application of literacy skills to media and technology messages. As communication technologies transform society, they impact our understanding of ourselves, our communities, and our diverse cultures, making media literacy an essential life skill for the 21 st century.' ${ }^{4}$

It becomes increasingly obvious in the debates that the European exchange is hardly facilitated not only by the languagetheoretical roots of the literacy concept but also by the various linguistic and cultural traditions as well as the performative characteristics. This is apparent particularly from the integrative efforts in the context of the European Charter for Media Literacy 5 which pointedly describes the following, among other things:

"media literate people should be able to:

- Use media technologies effectively to access, store, retrieve and share content to meet their individual and community needs and interests;

- Gain access to, and make informed choices about, a wide range of media forms and content from different cultural and institutional sources;

- Understand how and why media content is produced;

- Analyse critically the techniques, languages and conventions used by the media, and the messages they convey;

\footnotetext{
${ }^{3}$ Previously Alliance for a Media Literate America (AMLA)

${ }^{4}$ Cf. <http://www.amlainfo.org/home/media-literacy/>.

${ }^{5} \mathrm{Cf}$. url=http://www.euromedialiteracy.eu/charter.php
} 


\section{CONTEXT LEVELS}

I Personal/individual level; Dispositional influence

II Situational level; Influences of the specific situation

III Systemic level; Social, cultural, political context

\section{COMPETENCE CYCLE}

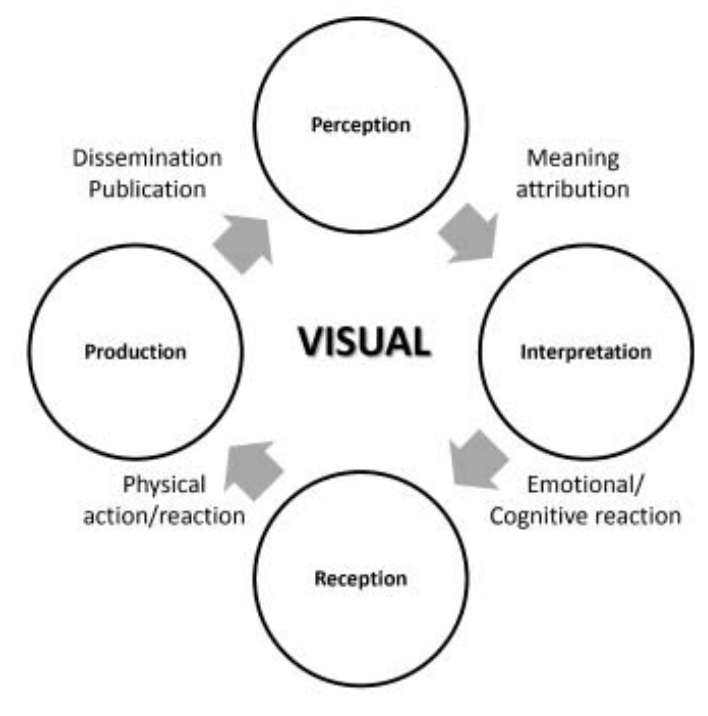

Fig. 1. Visual competence cycle [50, p. 103]

- Use media creatively to express and communicate ideas, information and opinions;

- Identify, and avoid or challenge, media content and services that may be unsolicited, offensive or harmful;

- Make effective use of media in the exercise of their democratic rights and civic responsibilities." (ibd.)

Even though representational and conceptual as well as practical and application-oriented aspects remain to be discussed in detail, the international communication efforts have set in motion important debates which can be related to discourses of educational theory (Bildungstheorie), life competence (Lebenskompetenz) and the art of living (Lebenskunst).

\subsection{Visual competence and visual literacy}

Similar extensions and differentiations can be reconstructed by means of the terms 'visual competence' (visuelle Kompetenz), 'image competence' (Bildkompetenz), 'visual literacy' (Bildliteraltität), 'visual education' (visuelle Bildung) and also 'visual learning' (visuelles Lernen). Especially in educational contexts these expressions refer to related semantic fields, sometimes being used synonymously.

In the German-speaking world, Christian Doelker in 1997 was the first to use the terms with a media-pedagogical intention and propose a differentiated concept [11] which included receptive and creative dimensions. A core part of his concept is the image-semantic layer model. Visual competence here refers to those abilities and skills which are necessary for exploring the tectonics of subjective, inherent and intended meanings and of the qualities of visuals (validity, comprehensibleness, coherence, tenability). In regard to the literality of images, Doelker's argument is based on an extended notion of reading
[11. p. 151], which is significant not least for the clarification of artistic claims.

"The term Literalität [literality] is not to be confounded with 'Literalität' as the 'German' counterpart of literacy $=$ reading competence." [11, p. 151], italics in original]

Accordingly, Doelker works with a broad definition of 'reading' which relates to all forms of recorded configurations in and with which meanings can be discerned, for example, when literality in the sense of scripturality (Schriftlichkeit) and imagery (Bildlichkeit) refer to each other. This effort can be interpreted as an effort for (a) a kind of freeing educational foundations from restrictions to words and texts as core elements of higher educational processes, and (b) for revalueing visual education after the long lasting "battle between words and images" [21].

What Doelker considers to be an expansion based on visualtheoretical and educational-policy motivations, others, among them Müller [50], view as a relatively narrow 'literacy approach' which does not cover many aspects relevant for their (broader) idea of 'visual competence' [50, p. 102]. Their research group regards the latter as an interdisciplinary concept, more specifically, a paradigm for "basic research on the production, distribution, perception, interpretation and reception of visuals, aimed at understanding visual communication processes in different contemporary social, cultural and political contexts" [50, p. 103].

This model (see Fig. 1) aims at an overarching visual approach which unites all social sciences. It distinguishes four areas of competence which are dynamically related:

"Visual competence, [...], is subdivided into four intertwined, but still distinct competencies: perceptual competence, decoding and interpretation competence, production 
competence, and intra- as well as intercultural perception competence." [50, p. 105]

(http://www.nytimes.com/2012/06/03/magazine/craigventers-bugs-might-save-the-world.html?pagewanted=all, accessed June 25, 2012) [66].

Correspondingly, pedagogical standards of dissemination are located as subordinate aspects in a comprehensive concept of visual communication.

On the other hand, there are contrasting relativizations, for example, by Lothar Mikos [46], who regards visual competence as a precedent area of media competence. He argues for paying more attention to non-discursive esthetic experiences and adding presentation elements to discursive media competence [46, p. 10]. He bases his argument on Mannheim's notion of 'conjunctive experiential space' [46, p. 2], and emphasizes aspects of socialization theory that pertain to the subject matter. Another example provides Ludwig Duncker [12] who calls for a "grammar of seeing" and an "aesthetical alphabetization" based on 'visual literacy' (Bildliteraltität). In doing so, he considers the concept of literacy as superior in relation to the concept of competence, at least as a starting point for educational processes. Moreover, "Competencies of Visuals" [57] and their epistemological relevance are intensively discussed in arts, architecture, philosophy as well as in educational, communication, and media studies.

\subsection{New literacies}

As we have already seen in the introduction, there are many more compound terms making use of literacy approaches in one way or another. Most recently, calls for new skills and abilities, so-called new literacies, have entered the picture [73, pp. 45-47]). What does this mean? How do "traditional" areas of reading, writing, information, image and media competence relate to new skills such as multitasking, transmedia navigation or networking?

Renee Hobbs, in her latest synopsis of debates about new literacies, distinguishes four approaches: "media literacy, information or ICT literacy, critical literacy, and media management" [27, p. 433]. On the one hand, these approaches are quite similar to one another in regard to aspects like the constructed nature of authorship and audiences within socio-cultural contexts, the circulation of messages and meanings, and to "an exploration of questions about how texts represent social realities, reflect ideologies, and influence perception, attitudes and behaviors about the social world and one's place in it" [27, p. 437]. On the other hand, they are linked with various framings and focusings of problems together with correspondingly different proposals for solution.

As an example, I want to draw on the white paper by Henry Jenkins et al. [31], which-based on current social challenges of media convergence, participation and collective intelligencefavors a (media-)ecological approach:

"Rather than dealing with each technology in isolation, we would do better to take an ecological approach, thinking about the interrelationship among all of these different communication technologies, the cultural communities that grow up around them, and the activities they support. Media systems consist of communication technologies and the social, cultural, legal, political, and economic institutions, practices, and protocols that shape and surround them."

[31, p. 8].

Forms of problem solving and learning with a playful approach hold a special importance ${ }^{6}$ The authors list the new skills and abilities as, for example, "Play — the capacity to experiment with one's surroundings as a form of problem-solving follows", "Appropriation - the ability to meaningfully sample and remix media content" or "Collective Intelligence — the ability to pool knowledge and compare notes with others toward a common goal" [31, p. 4], bold in original.

The authors emphasize the crucial role of "social skills" and "collaboration and networking" (ibd.). They gear their remarks at "average consumers" and point out the connections to traditional forms of literacy:

"These skills build on the foundation of traditional literacy, research skills, technical skills, and critical analysis skills taught in the classroom" [31, p. 4 bold in original].

There is no doubt that this white paper presents important aspects that are worthy of discussion and attention in the context of contemporary debates about media competence and media literacy. However, this statement is meant in the sense of critical considerations rather than in a simple affirmative sense because the focus on popular cultural developments (for example remix cultures, modding, fan fiction, videogames) points to an understanding of the problem that is primarily directed to Northern American circumstances and in which intercultural, educationpolicy and economic aspects receive extremely little attention.

To what extent do the new literacies represent trend-setting concepts and inevitable innovations in the light of mediacultural developments? To what extent do the new literacies constitute the problem that they are pretending to solve? I do not think there are general or easy answers to these questions. However, in my view the ongoing processes of the literacification of everything are rather part of the problem than of the solution.

\section{On the literacification of everything: desiderata and shortcomings in the case of visuals}

No matter if we understand literacy in a narrower sense of the ability to read and write or the socio-cognitive process of gaining meaning from print, in a wider sense of the ability to use language proficiently in various contexts, or in the widest sense of being knowledgeable in a particular field or the ability to deal with a variety of symbol systems and to understand all forms of communication including relevant cultural, economical, politi-

\footnotetext{
${ }^{6}$ Cf. for instance the applications of the "Education Arcade," available online at http://www.educationarcade.org/.
} 
cal, historical, and medial contexts, the particular understandings are rooted in the history of writing and primarily related to developments of expressing language by letters or other marks.

When it comes to 'visual literacy', we should be aware that no matter where we start in history, from the cave paintings of the Cro-Magnon people to the "networks of emerging iconocracy" [18], visuals and questions of visuality have always been significant for many processes of human communication, education and knowing. Moreover, pictures have been created more than 30.000 years before writing was developed 7 Howsoever we conceptualize the relation of visuals, words, writing, and language, and no matter which shape we give to the disruptions and continuities here in view of long-term media dynamics, new emphases and developmental dynamics, qualitatively and quantitatively different from earlier ones, have been emerging for a while. The proliferation of digital image editing technologies and not least the mass use of web-based image and video platforms have been accompanied by a quantitative increase of images, unlike with any other historical advance of visualization.

The quantitative boosts of visualization can be illustrated quite easily by the fact that, for example, on average more than 300 million photos have been uploaded to Facebook per day during the first three months of $2012{ }^{8}$ As to Youtube, every minute 60 hours of video material are being uploaded and more than four billion video clips are being activated every single day 9 Moreover, along with digitalization dynamics a vast amount of new visualization tools and methods are being created and applied in many fields. Efforts to provide overviews in this situation remind us of the myth of Sisyphos. And suggestions of completeness figured like, for example, in the "periodic table of visualization methods" (see Fig. 2) and other assortments of tools and methods 10 should not mask the fact that there are multitudinous options available in the fast developing digitized worlds and that analogue visualization modes using both material tools (cf. sketching, drawing, painting, etc.) and mental tools (cf. envisioning, imagining, bringing something to mind, evoking mental movies, etc.) are still at work with or without making use of digital tools.

Even though research dealing with quantitative dynamics and their effects, for example, on everyday practices, socialization processes, or collective and individual politics of memory, is still in its early stages qualitative aspects are widely and even more underestimated. It is precisely the recollection of epistemic functions of pictures and images which gives reason for questioning argumentations drawing on the primacy of literacy

\footnotetext{
7 Cf. http://www.spektrum.de/alias/hoehlenmalerei/frueheste-felskunsteuropas-rund-37-nbsp-000-jahre-alt/115189, accessed: May 22, 2012.

${ }^{8}$ Cf. http://newsroom.fb.com/Key-Facts/Statistics-8b.aspx, accessed: June 22, 2012. Even if Jonathan Good's [24] estimations are outdated by now, they give an impression of ongoing quantitative dynamics when he states that Facebook's photo collection is more than 10,000 times larger than the collection of the Library of Congress (ibd.).

${ }^{9} \mathrm{Cf}$. http://www.youtube.com/t/press_statistics, accessed: June 22, 2012.

${ }^{10} \mathrm{Cf}$. for instance http://www-958.ibm.com/software/data/cognos/manyeyes.
}

as pivot for human cognition and understanding.

Tellingly, media philosophical argumentations have been widely ignored in discourses on visual literacy. This concerns particularly the non-verbal logic of pictures [7] and the importance of non-verbal symbols including visual symbols for rational thinking. Of course, there are reflections regarding referential contexts between picture and writing or verbal explanation in discourses on visual literacy, too. But relevance and scope of picture theories for knowing and reasoning are undervalued in these discourses at large, although differentiated argumentations are available since decades. This involves milestones like Rudolf Arnheim's Visual Thinking [2], authors who referred to Wittgenstein's work like Karlheinz Lüdeking [41], Gregory Scherkoske [61], and Kristóf Nyíri [51], [53, pp. 7397], and also hermeneutic and media phenomenological considerations of visual argument 11 [45] and epistemic metaphors and the cognitive significance of images [77, pp. 23-127].

While the significance of changing viewing practices and ways using visuals for processes of knowledge and communication is reassessed and the "logic of the pictorial" (Logik des Bildlichen) [26] is being addressed, we have to be aware that the processes of "visualizing imaginary things which do not exist for our senses" [17, p. 290f], imply new questions and reflections. Moreover, debates about anthropological, epistemological and ethical challenges related to recent developments in the field of synthetic biology have started just recently. These debates go far beyond previous arguments concerning the relevance of pictures and images in relation to text for triggering or creating desires. They concern the interplay of media and life in the sense of "biomedia" [76] as new medial forms.

With a view to biological processes elicited by computer technologies and acting as media and especially to biocybernetic reproductive technologies, W. J. T. Mitchell writes:

"[T]he oldest myth about the creation of living images, the fabrication of an intelligent organism by artificial, technical means, has now become a theoretical and practical possibility, thanks to new constellations of media at many different levels. The convergence of genetic and computational technologies with new forms of speculative capital has turned cyberspace and biospace (the inner structure of organisms) into frontiers for technical innovation, appropriation, and exploitation-new forms of objecthood and territoriality for a new form of empire." [48, p. 309; italics in original].

The history of imaginations of the possibilities in regard to the realization of them and their reflection is thus set in motion again. New forms of the intentional materialization of imaginations are coming into consideration; at least that is suggested by multi-billion investments in genetic engineering research. In

${ }^{11}$ See also the Peter Bexte's project on visual ar-
gumentation

berlin.de/v/embodiedinformation/projects/index.html)" 


\section{A PERIODIC TABLE OF VISUALIZATION METHODS}

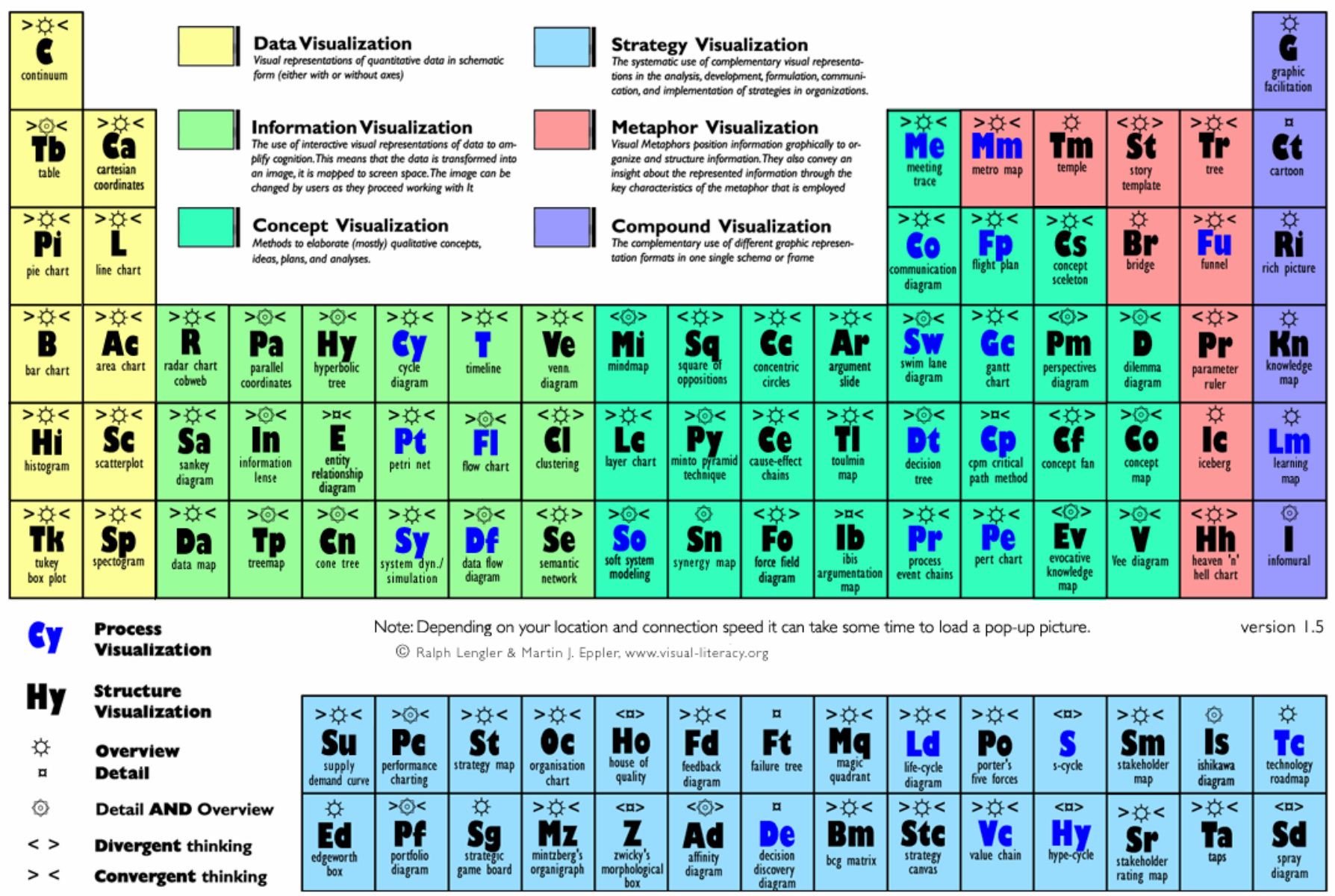

Fig. 2. Visualization methods (@ Lengler \& Eppler, cf. http://www.visual-literacy.org/periodic_table/periodic_table.html, accessed: June 18, 2012)

the interplay of bio- and computer technologies, computed images can become alive in a material sense which goes beyond esthetically motivated forms of the digital techno-genesis of the visible (for instance in the movie industry) 12 The metaphor at least suggests a new way of reading the antecedence of images. In his book Ein Bild ist mehr als ein Bild (An image is more than an image) [11], Christian Doelker lists several variants of the dictum "In the beginning, there was the image":

"writing was preceded by the petroglyph, articulated language by the mimic expression, rational thought by the mythical belief" [11, p. 16].

In the age of biocybernetic reproducibility, one might add to that: the creation of synthetic cells is preceded by the vision of artificial life on the drawing board, or better, via computers programmed by bio-engineers ${ }^{13}$

\footnotetext{
${ }^{12}$ Cf. for instance the science fiction movie Gattaca (director: Andrew Niccol, 1997) about genetically engineered strategies of "optimizing" human life and their impact on society.

${ }^{13}$ After all, this year Craig Venter and his team succeeded in creating a living bacteria cell which is controlled by a chemically synthesized genome (see $<$ http://www.ted.com/talks/lang/eng/craig_venter_unveils_synthetic_life.html>) - "A first breeze of artificial life," said the title of Sven Stockrahm's article in the online edition of Die Zeit from May 20, 2010 (see
}

Even if the bio-cybernetic developments are just beginning and costly in many ways, along with them, new challenges for media anthropology, media epistemology ${ }^{14}$ media criticism and not least for media communication and media pedagogy are beginning to show. Although there is no "literacy bug" in sight so far-maybe except for those in the figurative sense of the literacification dynamics mentioned above- wide parts of concurrent discourses on visual literacy seem rather odd and restricted to the thinking of the linguistic turn. But today, dealing with the methodological and epistemological challenges linked with the pictorial turn [47] and the iconic turn [7, p. 13f], is long overdue. Moreover, also in view of discourses on one or several mediatic turns [20, 29, 43] and the digital turn [34] it is about time for considerations beyond literacies.

http://www.zeit.de/wissen/2010-05/Bakterium-kuenstliches-Leben). The story goes on with a new chapter on designer bugs which -according to Craig Venter"might save the world" (http://www.nytimes.com/2012/06/03/magazine/craigventers-bugs-might-save-the-world.html?pagewanted=all, accessed June 25, 2012) [66]

${ }^{14}$ Cf. especially Schmidt [62] and Faßler [17 p. 293]. This also presents new challenges to approaches of third-order cybernetics, such as the ones brought forward in the context of the theory of organizational development [32]. 


\section{Towards conceptual considerations beyond litera-} cies

In view of these arguments I come to the preliminary conclusion that at least wide parts of the newer literacy discourses rather obscure or misconstrue basic dynamics of understanding and dealing with digital media. There is the need of reflections on limitations of linguistic concepts. For example, in the context of the discourses on media competence, the language-theoretical roots of the competence concept have long represented a blind spot and in many places continue to do so. The situation is similar with the roots of the literacy concept. Especially the "new literacies" show that the figurative transfer of literacy to many different contexts is debatable since it is less about writing than about aspects of educability, orientation and understanding, and the ability to act appropriately in a given situation.

Without a doubt, along with the media-cultural developments particularly in the past twenty years, the spectrum of questions and topics pertaining to the skills of written culture has expanded as well. In this respect, it is also a concern to further define literacy as an educational task [6]. Yet, the basic assumption that social life "is overall determined by forms of written communication" [25, p. VIII], must be qualified today in light of processes of medialization and mediatization [42]. As far as I can see, many contemporary authors who are aware of pictorial, mediatic and digital turns would approve of such a relativization of the relevance of written culture and communication. Opinions are divided over the question of how it can and should happen and which conceptualizations appear useful for which purposes.

If we take a step back and start to explore considerations beyond literacies we can distinguish various forms and modalities. There is a continuous spectrum of more or less consequent and narrower and wider scopes of consideration. On the one hand, we have approaches starting from within in the sense of explorations of practices and conceptualizations aiming at a better understanding of literacies and corresponding limitations. In addition, there are approaches going beyond in terms of describing connections to related but distinct realms like picturacy and mathemacy. On the other hand, there are epistemological and media-theoretical claims which emphasize foundations and a wider picture. In the following passages I am going to sketch a few examples of available, plausible and promising considerations.

\subsection{From literacies to clarifications of relations of literacy,} mathemacy, oracy, and picturacy

Looking at the need for clarification, Street \& Lefstein [73. pp. 46-47], suggest to resolve the conceptual confusion by means of two strategies: On the one hand, they encourage separate studies in which the analyzed objects are clearly defined and terminologies clarified by means of ethnographic methods in the sense of a "closeness to the ground" [73, p. 46]. On the other hand, they argue for reflecting the significance of (new) literacies for the persons concerned by the area of conflict between life-world aspects and "new work orders" (ibd.). As to the terminological differentiations claimed by the authors, there are definitely studies available in which also epistemological dimensions beyond single-discipline aspects receive attention (e.g. [54 55]). In addition, numerous points of contact exist in regard to the political dimensions, ranging from considerations of ideological critique [22] to critical visual-pedagogical approaches to the context of political education [28].

This does not exhaust the need for clarification, however. Even though the epistemological dimensions are often highly neglected in single-discipline studies and the call for application-oriented concepts is virtually ubiquitous, not least in media pedagogy, I do not see a way around basic theoretical reflections here. In my opinion, they reach beyond (questions of) literacies at least in a twofold sense. Widespread modalities of the "universal pragmatic" connection of literacy to various areas of phenomena, such as outlined above, all too easily hide the fact that letters, words, images ${ }^{15}$ numerals, formulas, etc. are linked with various forms of meaning creation, significance attribution and knowledge building. In my view, we should better clarify the characteristics of literacy, numeracy or mathemacy, oracy and picturacy and their relations than create expansions in the sense of mathematical, quantitative and visual literacy or apply metaphorical uses in the manner of everyday theory. In this regard, Gunther Kress proposes the following naming practice:

1 "words that name resources for representing and their potential - speech, writing, image, gesture;

2 words that name the use of the resources in the production of the message - literacy, oracy, signing, numeracy, (aspects of) 'computer literacy' and of 'media literacy', 'internetliteracy'; and

3 words that name the involvement of the resources for the dissemination of meanings as message - internet publishing, as one instance" [36, p. 23].

This suggestion has not yet been seized on a broad basis, although it establishes useful ideas for a differentiated handling of the subject matter. Moreover, it could be further refined, for example, with respect to considerations of the whole spectrum of (critical) mathematical thinking including numeracy as part of it [69 70] and the development of a Number Sense [10]. Furthermore, the proposal could be enhanced by way of connecting it to questions concerning design theory [38] and the logic of images [26,52].

\subsection{Literacy and visuacy - action, activity and actionism}

In contrast to narrower linguistic understandings of literacy [25] enhanced versions take socio-cultural and selected contextual aspects into account. Some of these approaches remain

\footnotetext{
${ }^{15} \mathrm{Cf}$. the distinction of pictures, images and icons and the problematization of the "world's readability as caretaker of the written universe against the invading images" [17. p. 29]
} 
ambivalent in the sense of metaphorical applications of literacy concepts. For example, notions on situated literacies [5] clearly go beyond traditional understandings by focusing on (literacy) practices and social dynamics at the same time carrying old epistemological burdons.

In social semiotics enhancements of older literacy concepts are being developed more consistently aiming at a general framework beyond linguistic origins and taking into account the growing importance of sound and visual images [36, 37]. Similarly, activity theorists conceptualize cognitive acts in relation to everyday practices arguing against assumptions of cognitive acts like decision making, knowing, classification, or remembering as discrete and disembodied acts [15]. But so far, critical appraisals of potential argumentations beyond literacies on the basis of this framework are missing. Of course, visuals play a role in this framework, too. But they are - together with print texts, computers, etc. - rather taken as tools of literacy which "influence and constrain the actional level of meaning making" in a classroom - or: "In other words, the field of material semiotic objects (texts, graphs, images, etc.) defines the psychological goals as well as the certain type(s) of literate actions" [35]. This approach my help to overcome all too narrow conceptualizations of literacy as an isolated entity decoupled from action, talk, tools, objects, and spaces. But the way the focus is put on the whole does not consider fruitful potentials of distinctions and relations between literacy and visuacy or picturacy. Accordingly, the Literacy Learning Activity System (LLAS) is missing its complement, a Picturacy Learning Activity System (PLAS).

As to educational contexts integrated systems in which knowing, distinguishing and discovering through acting play a role are helpful especially if relations between everyday knowledge, scientific knowledge and school knowledge as well as social relations and learning activities in various contexts are taken into account [59]. But it is one thing to consider, for example, pedagogical genres as integrating perspectives. And it is another thing to be mindful of both distinctions between verbal and pictorial expressions as well as similarities of them as means of communication [33, pp. 114-121] in the context of integrating perspectives 16

Efforts of thinking beyond literacies in terms of socially situated, culturally contextualized or embodied practices might be too short-sighted if we look at activist media and practices of media disobedience that challenge the dominant culture. Discourses on media activism [44,75] offer many points of reference for thinking and acting beyond governmentalization or academic forms of thematization of literacies. There is a broad spectrum of activities including graffiti, radio activism, community media, visual activism, tactical media, and more recently,

\footnotetext{
${ }^{16}$ Just recently Kristóf Nyíri pointed out that - even if we accept the visual as more fundamental than the verbal - both verbal and pictorial expressions are grounded in motor dimensions 53 p. 125]. It seems that conceptions of embodiment and embodied cognition [65] have been widely underestimated in discourses on literacy and picturacy.
}

media interventions questioning the workings of biopower [9]. While institutionalized learning activities are only partially concerned with exposing the shortcomings of democracy, practicing civil disobedience, promoting moral courage and resistance opposite problematic mainstream developments media activist interventions aim questioning mainstream media offers, naming practices and established but doubtful meanings and practices of meaning-making. For example, the case of "visual activism" David Sheridan and others [67] describe shows how students can act as activist rhetors, being engaged in both meta-discursive activities and media interventions. The pedagogy they suggest does not focus specifically on visual activism. Instead, their approach "foregrounds decisions about mode, media, and technologies as kairotic choices" (ibd.).

\subsection{Media theoretical perspectives}

So far, we have seen that there is a variety of starting points for considerations beyond literacies opening up different horizons for further development. Some are focusing micro-levels of individual or social actors, others are foregrounding sociocultural aspects or the work of media or the social, and others again include macro-levels further developing Eric Havelock's and Walter Ong's ideas about transitions from orality to literacy to visuacy and mediacy. Furthermore, we find various methodologies and understandings of critique as well as foundational and use inspired or applications oriented studies. The question remains how to bring together idiosyncratic and structural or systemic perspectives and also symbolic and material dimensions of literacy and visuacy functions in mediated and mediatized environments.

If we take the role of verbal and pictorial expressions as means of communication, education and explanation seriously, and if we take the relevance of virtual objects and connections into account, too, it becomes quite obvious that epistemologies in the light of the linguistic turn do not suffice as basis for apt conceptualizations beyond literacies. We rather need media epistemological approaches which accept that in everyday thinking and in academic thinking verbal and non-verbal symbols, and especially visual symbols are crucial.

Among the many media theoretical approaches being discussed today I want to highlight the theory of medial forms [39] at this point. The core of this middle range theory is a flexible concept of form dynamics which enables description and analysis of exchange processes between different media as well as between mass media and arts. This theory is a consistent further development of Ernst Cassirer's concept of symbolic forms. It is compatible with narrower concepts of schemata formation ${ }^{17}$ [79] and with wider theories of media dynamics [60] and mediacultural philosophy [63]. Accordingly and in contrast to both rather concrete and very abstract conceptualizations (see Fig. 3) the theory of medial forms is versatilely applicable.

\footnotetext{
${ }^{17}$ For the time being, its connectivity with Kant's wider concept of schema(s) [52] is subject to clarification.
} 


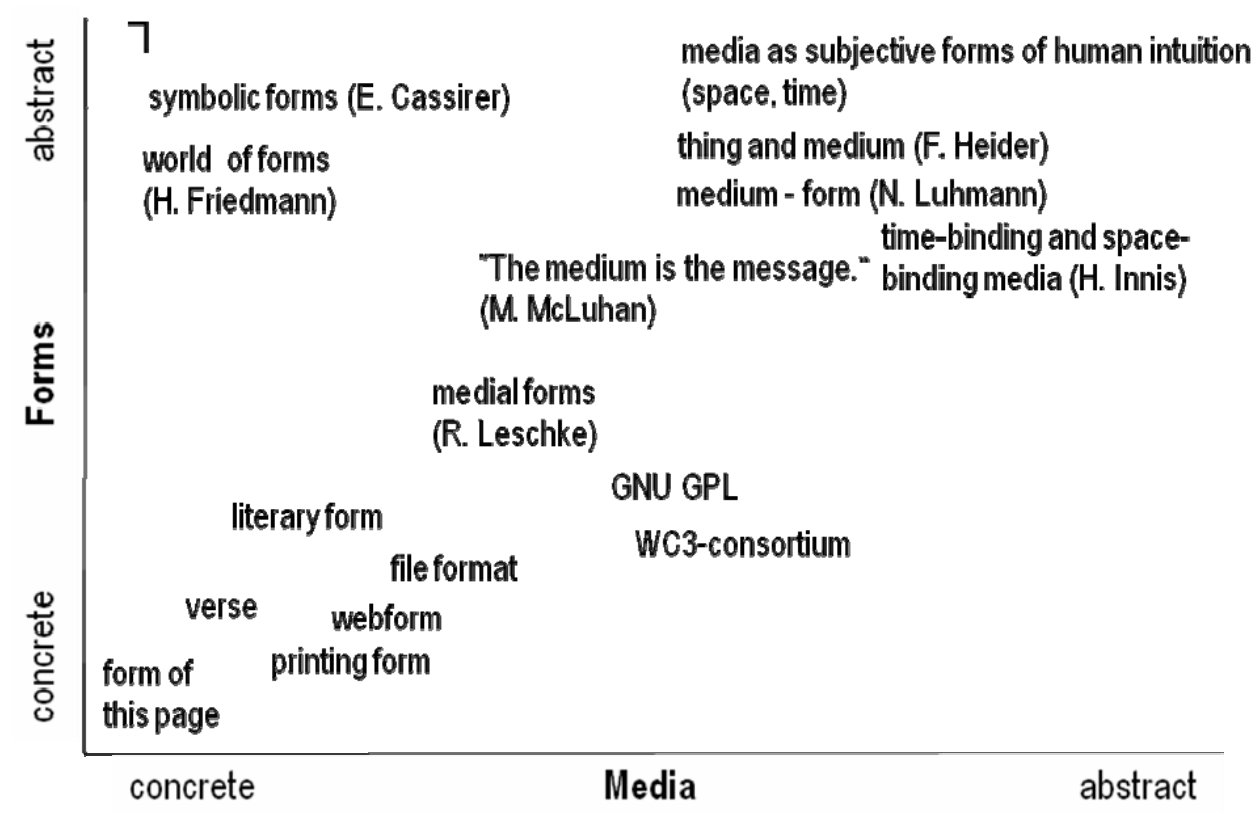

Fig. 3. Forms and media: Scopes and selected examples (illustration by Theo Hug)

The fact that there is reason to doubt "whether it [...] makes sense that the internal differentiation of a knowledge system continues to be oriented on the individual media and their apparatuses" [39. p. 303], suggests questions about cross- and transmedial forms of knowing. Consequently, we should ask how resources like writing, numbers, image, or gesture are appearing in medial forms, and in which ways certain forms of literacy, mathemacy, oracy or picturacy are being relevant, and how practices of embodiment are being established in which communicative, cultural or educational contexts.

To conclude, the key function of media forms in a transversally integrated media system is relevant not only to media theory. To the extent that they represent "just as well the material of media communication as the aspect of the ideal of media technology," they are connected with objections "to the culturalscientific neglect of technology and to a monovalent technodeterminism" [39, p. 300]. What is even more, the theory of the dynamics of media forms also offers trend-setting perspectives of how to account for demands concerning the conceptualization, composition and critique of visual competence as well as of media competence and media education. These are not established once and for all on the basis of (un)critical statements but consistently developed anew as moments in the (co-)evolution of medialized configurations.

\section{Conclusion}

Metaphorical enhancements of literacy concepts and their applications rather obscure than clarify educational and epistemological aspects of contemporary media cultures and communication. Letters, words, images, numerals, formulas, conceptual schemata, gestures etc. are linked with various forms of meaning making, significance attribution and knowledge building. The modes of connections, related structures and practices as well as contextualizations can be analyzed by means of the theory of medial forms. In doing so, verbal and pictorial expressions - among others - can be treated as eigenvalues whose interplay in media systems constitutes specific form dynamics. Beside conceptual details relations of competence and performance, communication and education (Bildung) as well as literacy, mathemacy, oracy and picturacy are matters of investigation. Though, it seems important to overcome self-evident assumptions, such as the distinction of five senses, which on closer examination is anything but self-evident [74]. Presumably, these and similar basic distinctions relevant to perception can be relativized most likely in the context of polylogic approaches to research [78].

Of course, it would be easier to restrain studies to measurable media competencies or to abstract media critique. But dangers of self-sufficient rhetoric or oversimplified questions in the name of educational policies should not be ignored if we want to achieve deep understanding of our contemporary media cultures and contingent forms of knowledge.

As to institutionalized education, large parts of it can be taken as examples demonstrating how much literacy-based forms of the communicative stabilization of learning cultures can restrict the probing of creative, conceptual and critical-reflexive scopes. While media literacy is being discussed as an alternative to media regulation [27, pp. 443-444], schools are widely administered in the sense of "monomedial provinces" [8]. Suggestions for Media Education in New Cultural Spaces [4] have led to school trials and pilot projects here and there, but over large parts, school is designed in terms of a "literal counterculture" or a "media-resistant polis" [8]. Admittedly, Franz Pöggeler wrote twenty years ago:

"The fact that pedagogy and educational science these days pay closer attention than in the past to images, next to print media, is certainly a result of the new weighting 
of the verbal-literary component of education in relation to the visual one: In our society's communication and information system, visualization is playing an ever increasing part. Print media are losing some of their prestige and impact even within the school system, whose history was largely identical with that of the spread of writing." [56. p. 11]

However, it seems to be a long way to the realization of new educational potentials of transmedia network cultures [8]. In this regard, I think that two aspects are especially important for further consideration: (1) The debates about media competence have reached a point at which the opposition between technophobic humanities and cultural studies, on the one hand, and techno-euphoric engineering and natural sciences, on the other, has become historically obsolete. This corresponds (2) with a need of rethinking the Enlightenment [13] especially in terms of context-dependence of all knowledge. Though, we might consider "educational amateurs" [19] showing alternatives to one's release from his or her 'self-incurred tutelage' (I. Kant) in terms of self-generated and self-organized maturity (Mündigkeit).

\section{References}

1 Adams K, Interview with the founding father of the competency approach: David McClelland, Competency 4 (1997), no. 3, 18-23. Retrieved on February 3, 2011 from http://orientamento.it/orientamento/8c.htm.

2 Arnheim R, Visual Thinking, Berkeley: University of California Press, 1969.

3 Baacke D, Kommunikation und Kompetenz: Grundlegung einer Didaktik der Kommunikation und ihrer Medien, Juventa, Munich, 1973.

4 Bachmair B (ed.), Medienbildung in neuen Kulturräumen: Die deutschsprachige und britische Diskussion, Wiesbaden: VS Verlag für Sozialwissenschaften, 2010.

5 Barton D, Ivanic R, Hamilton M (eds.), Situated Literacies: Theorising Reading and Writing in Context, New York: Routledge, 2000.

6 Bertschi-Kaufmann A, Rosebrock C (eds.), Literalität: Bildungsaufgabe und Forschungsfeld, Munich, Weinheim: Juventa, 2009.

7 Boehm G, Die Wiederkehr der Bilder, Was ist ein Bild? (Boehm G, ed.), Munich: Wilhelm Fink, 1994, pp. 11-38.

8 Böhme J, Schule am Ende der Buchkultur. Medientheoretische Begründungen schulischer Bildungsarchitekturen, Bad Heilbrunn: Klinkhardt, 2006.

9 Da Costa B, Philip K (eds.), Tactical Biopolitics: Art, Activism and Technoscience, Boston: MIT Press, 2008.

10 Dehaene S, The Number Sense: How the Mind Creates Mathematics, Oxford: Oxford University Press, 2011. Revised and Updated Edition, 1st ed. 1997.

11 Doelker C, Ein Bild ist mehr als ein Bild: Visuelle, Kompetenz in der Multimedia-Gesellschaft, Stuttgart: Klett-Cotta, 2002. 3rd ed., 1st ed. 1997.

12 Duncker L, Ästhetische Alphabetisierung als Bildungsaufgabe, Journal für politische Bildung 2 (2006), 12-24.

13 Elkana Y, Rethinking the Enlightenment, Approaching Religion 1 (2011), no. 2. Retrieved June 6, 2012, from: url=http://ojs.abo.fi/index.php/ar/article/view/117/97.

14 Elliot A J, Dweck C S (eds.), Handbook of competence and motivation., New York: Guilford Press, 2005.

15 Engeström Y, Miettinen R, Punamäki R-L, Perspectives on Activity Theory, Cambridge University Press, 1999.

16 Erpenbeck J, von Rosenstiel L (eds.), Handbuch Kompetenzmessung: Erkennen, verstehen und bewerten von Kompetenzen in der betrieblichen, pädagogischen und psychologischen Praxis, Stuttgart: Schäffer-Poeschel, 2007. (1st ed. 2003).

17 Faßler M, Vom Sichtbaren des Denkens, Kompetenzen der Bilder: Funktionen und Grenzen des Bildes in den Wissenschaften (Ratsch U. S., ed.), Tübingen: Mohr Siebeck, 2009, pp. 289-314.

18 Faßler M, Medien - Wissen - Bildung: Explorationen visualisierter und kollaborativer Wissensräume. (2010), 9-28.

19 Faßler M, Bildungsamateure $\mathcal{E}$ Wissensvektoren, 2012. (forthcoming).

20 Friesen N, Hug T, The Mediatic Turn: Exploring Concepts for Media Pedagogy, Mediatization: Concept, Changes, Consequences (Lundby K., ed.), Frankfurt a. M. et al.: Lang, 2009, pp. 63-83.

21 Fritze Y, Haugsbakk G, Nordkvelle Y, Visuell danning og kampen mellom ord og bilde. [Visual Bildung and battle between words and images.], Mediepedagogikk. Refleksjoner om teori og praksis (Vettenranta S. o. F., ed.), Trondheim: Tapir akademisk forlag, 2012, pp. 83-104.

22 Gee J P, Social Linguistics And Literacies: Ideology in Discourse, New York: Routledge, 1996.

23 Gee J P, Critical issues: Reading and the new literacy studies: Reframing the national academy of sciences report on reading, Journal of Literacy Research 31 (Sept. 1999), no. 3, 355-374, DOI 10.1080/10862969909548052.

24 Good J, How many photos have ever been taken?. Online-document, 2011. Retrieved June 6, 2012, from: http://blog.1000memories.com/94-number-ofphotos-ever-taken-digital-and-analog-in-shoebox.

25 Günther H, Ludwig $\mathbf{O}$ (eds.), Schrift und Schriftlichkeit: Ein interdisziplinäres Handbuch internationaler Forschung, Berlin, New York: de Gruyter, 1994/1996. 2 vols. (= HSK 10).

26 Heßler M, Mersch D (eds.), Logik des Bildlichen: Zur Kritik der ikonischen Vernunft, Bielefeld: transcript, 2009.

27 Hobbs R, Debates and challenges facing new literacies in the 21st century, International Handbook of Children, Media and Culture (Livingstone S. \& D., ed.), London: Sage, 2008, pp. 431-447.

28 Holzwarth P, Bildpädagogik und Medienkompetenzentwicklung als politische Bildung, Jahrbuch Medienpädagogik 7. Medien. Pädagogik. Politik (Moser H. S., ed.), Wiesbaden: VS Verlag für Sozialwissenschaften, 2008, pp. 97-116.

29 Hug T (ed.), Mediatic Turn - Claims, Concepts and Discourses / Mediale Wende - Ansprüche, Konzepte und Diskurse, Frankfurt a. M. et al.: Lang, 2009.

30 Institute of Museum and Library Services, Museums, Libraries, and 21st Century Skills (IMLS-2009-NAI-01), Washington, D.C., 2009. Retrieved April 15, 2010, from: http://www.imls.gov/pdf/21stCenturySkills.pdf.

31 Jenkins $\mathbf{H}$, Confronting the Challenges of Participatory Culture: Media Education for the 21st Century, 2006. White paper co-written for the MacArthur Foundation. Retrieved April 15, 2010, from: http://www.projectnml.org/files/working/NMLWhitePaper.pdf.

32 Kenny V, Boxer P, The Economy of Discourses: A Third Order Cybernetics?, Human Systems Management 9 (1990), no. 4, 205-224.

33 Kondor Z, The Verbal and the Sensual Mind - On the Continuity of Cognitive Processes, Bilder - Sehen - Denken. Zum Verhältnis von begrifflichphilosophischen und empirisch-psychologischen Ansätzen in der bildwissenschaftlichen Forschung (Sachs-Hombach K. \& T., ed.), Köln: Herbert von Halem Verlag, 2011, pp. 106-122.

34 Kossek B, Peschl M F (eds.), 'digital turn'? - Zum Einfluss digitaler Medien auf Wissensgenerierungsprozesse von Studierenden und Hochschullehrenden, Vienna: Vandenhoeck \& Ruprecht, V\&R Vienna University Press, 2012.

35 Kostogriz A, Activity Theory and the New Literacy Studies: Modelling the Literacy Learning Activity System. Paper presented in Sydney at the meeting of the Australian Association for Research in Education, 2000. Retrieved on July 8, 2012 from http://www.aare.edu.au/00pap/kos00161.htm.

36 Kress G, Literacy in the New Media Age, New York: Routledge, 2003. 
37 Kress G, van Leeuwen T, Reading Images: The Grammar of Visual Design, London: Routledge, 1996.

38 Krippendorff K, The Semantic Turn: A New Foundation for Design, Boca Raton, London, New York: Taylor \& Francis CRC, 2006.

39 Leschke R, Medien und Formen: Eine Morphologie der Medien, Konstanz: UVK, 2010.

40 Leu D J, The new literacies: Research on reading instruction with the Internet and other digital technologies, 1999. Online-document Retrieved July 15, 2010, from: http://www.sp.uconn.edu/ djleu/newlit.html.

41 Lüdeking K, Picture-Theory of Language and Language-Theory of Pictures, 1990.

42 Lundby K (ed.), Mediatization: Concept, Changes, Consequences, Frankfurt a. M. et al.: Lang, 2009.

43 Margreiter R, Realität und Medialität: Zur Philosophie des "Medial Turn.”, Medien Journal 23 (1999), no. 1, 9-18.

44 Meikle G, Future Active: Media Activism and the Internet, New York: Routledge, 2002.

45 Mersch D, Visuelle Argumente. Zur Rolle der Bilder in den Naturwissenschaften, Bilder als Diskurse, Bilddiskurse. Weilerswist: Velbrück (Maasen S. M., ed.), 2006, pp. 95-116.

46 Mikos L, Ästhetische Erfahrung und visuelle Kompetenz: Zur Erweiterung der diskursiven Medienkompetenz um präsentative Elemente, Vol. 1, 2000. Retrieved July 28, 2010, from: http://www.medienpaed.com/001/mikos1.pdf.

47 Mitchell W J T, The Pictorial Turn, Picture Theory: Essays on Verbal and Visual Representation, Chicago/London: University of Chicago Press, 1994, pp. 11-34.

48 Mitchell W J T, What Do Pictures Want? The Lives and Loves of Images, 2005.

49 Moser H, Grell P, Niesyto H (eds.), Medienbildung und Medienkompetenz. Beiträge zu Schlüsselbegriffen der Medienpädagogik, München: Kopaed, 2011.

50 Müller M G, Visual competence: A new paradigm for studying visuals in the social sciences?, Visual Studies 23 (2008), no. 2, 101-112, DOI 10.1080/14725860802276248.

51 Nyíri K, The Picture Theory of Reason, Rationality and Irrationality (Brogaard B. \& S., ed.), Wien: öbv-hpt, 2001, pp. 242-266. (preprint online available from http://www.hunfi.hu/nyiri/krb2000.htm, accessed June 6, 2012).

52 Nyíri K, Kritik des reinen Bildes: Anschauung, Begriff, Schema. Onlinedocument 2004. Retrieved August 20, 2010, from: http://www.philinst.hu/highlights/pecs_kant/Schema.htm.

53 Nyíri K, Zeit und Bild. Philosophische Studien zur Wirklichkeit des Werdens, 2012. Bielefeld: transcript.

54 Olson D R, Torrance N (eds.), Literacy and Orality, Cambridge University Press, 1991.

55 Olson D R, Torrance N (eds.), The Cambridge Handbook of Literacy., Cambridge University Press, 2009.

56 Pöggeler F, Bildung in Bildern - Versuch einer Typologie pädagogisch relevanter Bildformen, Bild und Bildung: Beiträge zur Grundlegung einer pädagogischen Ikonologie und Ikonographie (Pöggeler F., ed.), Frankfurt a. M. et al.: Lang, 1992, pp. 11-52.

57 Ratsch U, Stamatescu I-O, Stoellger P (eds.), Kompetenzen der Bilder: Funktionen und Grenzen des Bildes in den Wissenschaften, Tübingen: Mohr Siebeck, 2009.

58 Richardson J, The Internet literacy handbook, 3rd ed. Strasbourg: Council of Europe, 2009. Online-document, Retrieved July 6, 2009, from: http://www.coe.int/t/dghl/standardsetting/internetliteracy/hbk_EN.asp.

59 Rose D, Beyond Literacy: Building an Integrated Pedagogic Genre, Australian Journal of Language and Literacy 34 (2011), no. 1, 81-97, available at http://search.informit.com.au/documentSummary; dn= 729705401561987; res=IELHSS
60 Rusch G, Mediendynamik. Explorationen zur Theorie des Medienwandels., Navigationen. Zeitschrift für Medien- und Kulturwissenschaften 7 (2007), no. 1, 13-93.

61 Scherkoske G E, The Picture Theory of the Proposition in Wittgenstein's Tractatus logico-philosophicus, 1996. M.A. Theses (Dept. of Philosophy, Vancouver/CA, Simon Fraser University.

62 Schmidt S J, Blickwechsel: Umrisse einer Medienepistemologie, DELFIN 1997. Konstruktivismus in der Medien- und Kommunikationswissenschaft (Rusch G. \& S., ed.), Frankfurt a. M.: Suhrkamp, 1999, pp. 119-145.

63 Schmidt S J, Media Philosophy-A Reasonable Programme?, Philosophy of the Information Society. Proceedings of the 30th International Ludwig Wittgenstein Symposium Kirchberg am Wechsel, Austria 2007 (Hrachovec H. \& P., ed.), 2008, pp. 89-105.

64 Schorb B, Gebildet und kompetent: Medienbildung statt Medienkompetenz?, merz. Medien + Erziehung. Zeitschrift für Medienpädagogik 53 (2009), no. 5, 50-56.

65 Shapiro L, Embodied Cognition, London/New York: Routledge, 2011.

66 Sharp D, Craig Venter's Bugs Might Destroy the World. Online-document 2012. Retrieved on June 26, 2012 from http://www.biopoliticaltimes.org/article.php?id=6275.

67 Sheridan D, Michel T, Ridolfo J, Kairos and New Media: Toward a Theory and Practice of Visual Activism, 2009. Retrieved July 8, 2012, from: http://enculturation.gmu.edu/6.2/sheridan-michel-ridolfo.

68 Sheridan S R, A theory of multiple literacies. Online-document 2000. Retrieved October 2, 2007, from: http://www.drawingwriting.com/multlit.html.

69 Skovsmose 0, Towards a Philosophy of Critical Mathematics Education, Dordrecht/Boston/London: Kluwer, 1994.

70 Skovsmose O, Greer B (eds.), Opening the cage : Critique and Politics of Mathematics Education, Rotterdam: Sense, 2012.

71 Spanhel D, Medienbildung statt Medienkompetenz? Zum Beitrag von Bernd Schorb (merz5/09), merz. Medien + Erziehung. Zeitschrift für Medienpädagogik 54 (2010), no. 1, 49-54.

72 Sting S, Stichwort: Literalität - Schriftlichkeit, Zeitschrift für Erziehungswissenschaft 6 (2003), no. 3, 3317-337.

73 Street B V, Lefstein A, Literacy: An Advanced Resource Book for Students, London: Routledge, 2007.

74 Surana V, Indische Sinnesfelder in Alltag, Kunst und Philosophie, polylog. Zeitschrift für Interkulturelles Philosophieren 22 (2009), 15-24.

75 Sützl W, Hug T (eds.), Activist Media and Biopolitics: Critical Media Interventions in the Age of Biopower, Innsbruck: Innsbruck University Press, 2012.

76 Thacker E, Biomedia, Minneapolis: University of Minnesota Press, 2012.

77 Valkola J, Thoughts on Images. A Philosophical Evaluation, Bucharest: Zeta-Books, 2012.

78 Wimmer F M, Polylogische Forschung, (Einführung in die Methodologie der Sozial- und Kulturwissenschaften) (Hug T., ed.), Vol. 3, Baltmannsweiler: Schneider Verlag Hohengehren, 2001, pp. 382-393.

79 Winkler H, Schemabildung - Eine Maschine zur Umarbeitung von Inhalt in Form, Schemata und Praktiken (Conradi T. e. al., ed.), München: Wilhelm Fink, 2012, pp. 15-35. 